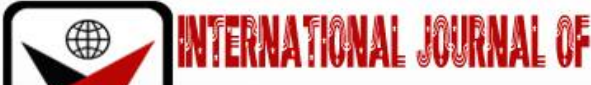

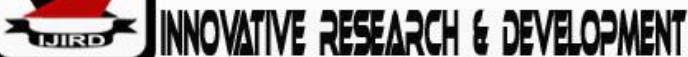

ISSN 2278-0211 (Online)

\section{Insurgency and Food Security in Ibadan: An Impact Assessment}

\author{
Adeboye, Francis Idowu \\ Post-Graduate Student, Department of Political Science and International Relations, \\ University of Abuja, Nigeria
}

\begin{abstract}
:
In recent times Nigeria has been plagued by insurgency in the North-East - a major food producing region and the country is apparently drifting into food insecurity. Boko-Haram insurgency in the North-East has affected food security by creating food shortages, which disrupt both, input markets and output markets, thus deterring food production, commercialization and stock management. This has dramatically changed the levels of agricultural production of the region that was known to have comparative advantage in the production of appreciable numbers of food crops for the nation. This research examined the impact of insurgency on food security in Ibadan; identified how insurgency has affected food chain supply and examined the coping strategies being employed by traders. Qualitative research design was used in the study. Interview guide and observation instruments were employed for data collection. The interview guide was administered on purposively selected sample at Bodija market. The interview guide was structured to elicit data relating to food availability before and during insurgency, and was administered on thirty selected beans and onion traders. Direct observation was also employed by the researcher to assess, among other things, the physical condition of the market and the condition of the commodities under study. Data collected was analyzed using transcription. Descriptive statistics was used to analyze the data generated from the questionnaire administered. Transcription was used for analyzing data generated from the interview guide. Comments were made according to the perception of the researcher based on observation. The findings show that insurgency in the North-East has reduced food availability in Ibadan. In order to live through difficult times traders have resulted to coping strategies involving the use of indigenous Northerners as food suppliers or middlemen, reduction in supply due to insufficient capital, joint purchase of commodities by traders, selling of non-essential assets to boost capital and concentration on commodities with minimum handling risk. Recommendations were made: confidence building through empathy and advocacy, improved government presence in the North-East, empowerment, local production of new crops, revitalization of the state grain reserve, etc.
\end{abstract}

Keywords: Insurgency, food security, Ibadan, Boko Haram, human need theory

\section{Introduction}

There is no doubt about the fact that food is life. Hence, food has become an instrument of national power. There are many examples of food insecurity in sub-Saharan Africa, some of them having reached catastrophic dimensions, for instance, in the horn of Africa or southern Madagascar. Food insecurity is not just about insufficient food production, availability, and intake; it is also about the poor quality or nutritional value of the food (FAO cited in Adeboye, 2015:1). The main goal of food security, therefore, is for individuals to be able to obtain adequate food needed at all times, and to be able to utilize the food to meet the body's dietary needs. However, achieving food security in its totality continues to be a challenge not only for the developing nations, but also for the developed world. In developed nations the problem is overcome by providing targeted food security interventions, including food aid in the form of direct food relief, or indirectly through subsidized food production. These efforts have significantly reduced food insecurity in these regions. The discrepancy in the results may be due to insufficient resource base, shorter duration of intervention, or different systems, most of which are inherently heterogeneous among other factors.

Attainment of food security is affected by a number of factors: These include unstable social and political environments that preclude sustainable economic growth, war and civil strife, macroeconomic imbalances in trade, natural resource constraints, poor human resource base, gender inequality, inadequate education, poor health, natural disasters, such as floods and locust infestation, and the absence of good governance. However, it has been observed that 'the new global threat to food security is conflict violence, especially insurgency' (Adebayo, 2015:3). The typical of which is Boko Haram operating in the north eastern of Nigeria. The escalation of the insurgency in early 2010 caught the government flat-footed. It initially believed the violence would die out (Daily Trust, Abuja, 8 August 2013). Sustained attacks, however, ushered in more sober responses. Since 2012, it has tried to address the challenge on multiple tracks but especially by increasing the defence budget from 100 billionaire (\$625 million) in 2010 to 927 billionaires (\$6 billion) in 
2011 and 1 trillion (\$6.25 billion) naira in 2012, 2013 and 2014(Leadership; 10 March, 2014). Much of these increases were to combat Boko Haram. Other measures include strengthening anti-terrorism legislation, boosting the capacities of the military and other security agencies, exploring dialogue with the insurgents, declaring a state of emergency in the North East and launching military offensives against the insurgents. Results have been limited. Undoubtedly, the devastating effect of the Boko Haram insurgency in the North is having its impact on other states in the country, especially when it has to do with the supply of foodstuffs. This therefore implies that the insurgency in the North has not only caused scarcity of certain commodities but has also affected the prices of these commodities in the market. In fact, cost of living has never been so high, and the masses are really complaining about the high cost of essential foodstuffs. The nation is also reeling from the severe impact caused by the Boko Haram activities. It has been reported that in Borno, Muhammed Namadi, the Borno State Farmers Association chairman said: 'Hundreds of farmers have been killed or forced to abandon rice and other crops ready for harvesting or just planted. Without immediate relief, farmers in Borno, who already live with abject poverty, insecurity and isolation, could also face widespread hunger. We have suffered a great deal as farmers in the last three years. The state should provide farmers with money and equipment. Many young and old farmers have been forced to leave their farms'. (The Sun; 3 Feb., 2014:14).

Nearly 20,000 farmers have been driven from their land by both the insurgency and the military crackdown under the state of emergency in Borno and two other North-Eastern states. According to the Borno state agriculture commission, many villages have been cut off from their farmlands by military road blocks while insurgents increasingly operate in the country side (The Sun; 3 Feb., 2014:14).In the situation created by the insurgency, hunger tends to be widespread in countries with high poverty levels. Hunger is likely to be more severe than poverty, especially when both are at elevated levels. As food is one of the most income-responsive of all basic necessities, boosting incomes and providing social safety nets reduce hunger. Where undernourishment is less prevalent than poverty, interventions to improve food utilization are required. The economy is feeling the brunt of the rising cost of food items, especially the rise in the prices of staple foods. Significantly, the price of rice has increased by over 100 per cent since 2006. It is instructive to note that Nigeria requires 2.5 million metric tons of rice annually while local rice production is less than half a million metric tons per year (Tell, May $5,2008: 23)$.

\section{Theoretical Frame Work}

This study anchors its analysis on the framework of Human Need Theory. All humans have basic human needs which they seek to fulfill and the denial and frustration of these needs by others could affect them immediately or later, thereby leading to conflict (Rosati et al 1990). Certain needs have been identified by the needs, theorists of the deprivation of which cause conflict. Maslow in his Motivation and Personality identified physiological needs, safety needs, belongingness and love, esteem and self-actualization. Burton cited in Adeboye (2015) refers to some needs as basic such as: food, shelter, sex and reproduction etc. Edward Azar names some basic needs like security, distinctive identity, social recognition of identity and effective participation in the processes that shape such identities (Azar cited in Ademola, 2012). The concept of hierarchy of needs derives from Maslow's (1943) more general theory of motivation and is based on the assumption that people are persistently motivated by one need or another. When one need is satisfied, it ordinarily loses its motivational power and is replaced by another one. Thus, as long as people's hunger needs are frustrated, they will strive for food, but once they have enough food, they move to other needs such as housing. According to Maslow, basic or lower-level needs must be satisfied at least to some reasonable degree before higher-level needs. In essence needs are arranged in hierarchy, with each ascending step representing a higher need, but one less basic to survival. Lower needs must be satisfied in order for people to strive for higher needs. However, there is no any automatic step. In fact, he contends that very few people step over this threshold. Physiological needs include food, water, oxygen, and so forth. They constitute the most basic or pre potent of all. People who are truly hungry are motivated to eat, not make friends or gain prestige. Physiological needs are different from other needs. They are the only needs that can be completely satisfied. However, they also have the attribute of recurrence. Even when we have had more than enough to eat, we will eventually get hungry and have to eat again. The other needs do not constantly recur. When the physiological needs are fairly satisfied, we become motivated by safety needs, including physical security, law and order, freedom from threats of illness, danger, anxiety, and so forth. Love and belongingness needs are next after safety and include the desire for friendship, the wish for a mate and children, the need to belong to a club, and host of others. Once these are satisfied, people then move to pursue esteem needs, such as confidence, self-respect, and the esteem of others. The final step is the move to selfactualization which Maslow suggests is very essential component of this postulation relates to the fact that even if one attains the upper-level needs, once the lower, more basic needs are deprived, the person ignores the higher needs in order to address the basic one. The Northern part of the country is the hardest hit by austerity, as the north-east \&amp; northwest zones have over 70\% poverty rates. Youths under 35years of age are the bulk of people in those zones living in penury and hopelessness. Boko Haram at the outset appeared to have had its operational bases located in the poorest parts of Northern Nigeria. It is in such places where people have been denied the opportunity to go to school as well as have meaningful economic sources of livelihood. Recruiting them for violent activities is the easiest. Boko Haram leaders are aware of it and of course are maximizing the advantage. Relating the Theory of Hierarchy of Needs to the proliferation of insurgency in Nigeria, the uncertainty in needs actualization by the masses has led to a perceived deprivation of the basic needs and has resulted in the very high rates of militancy that is being witnessed in Nigeria today. Physiological and safety needs predominate over those of esteem; loss of self-respect is no longer a sufficient deterrent. It is plausible that this factor may partially be responsible, for the current proliferation of insurgency in Nigeria. 


\section{Methodology}

This study is premised on a qualitative research method because of its relevance to the topic. Qualitative methods are typically more flexible - that is, they allow greater spontaneity and adaptation of the interaction between the researcher and the study respondents through the use of loosely structured open-ended questions. Qualitative method seeks to build a narrative about the issue of food security and insurgency. The technique enabled us access to get objective data and created inroad into the mind of the respondents. Generally qualitative technique provides greater insight into why and how people behave the way they do. The study population describes the entire people who stand to benefit from the findings of a study. Thus, Ibadan is the study population. The choice of Ibadan as our study population was influenced by some factors. Ibadan is a big and peaceful city. With such attributes it is envisaged that some of the internally displaced persons from the North East might be seeking a safe haven in Ibadan. In 2013 about 24 traders from Bodija market, Ibadan were allegedly killed by suspected members of Boko Haram while on business trips to Borno. However, being a very big city, it is practically impossible to cover the entire study population. Hence the need for a more precise target population to work with. Bodija market is the largest food stuff market in Ibadan and has also lost 24 traders to Boko Haram in 2013. This makes traders in Bodija market suitable as our target population. We are liable to obtain relevant data based on the recent loss of some traders to the insurgency on their way to Borno State. All people in Bodija market constitute the target population. Out of which beans and onion traders constitute the study sample.

The sample population was drawn from traders who usually travel to the North East to buy food stuffs and sell it in Bodija market. This was restricted to beans and onions sellers only due to the nature of the two commodities and impracticability in terms of resources to handle volume of data from all traders of all food items in a single study. The study employed purposive/judgmental sampling as a sampling modality for the administration of the research instrument. Purposive sampling technique has also been referred to as non-probability sampling or purposeful sampling. Also, purposive sampling technique involves selecting certain units or cases based on a definite purpose. A form of nonprobability sampling in which decisions concerning the individuals to be included in the sample are taken by the researcher, based upon a variety of criteria which may include specialist knowledge of the research issue, or capacity and willingness to participate in the research.

The researcher made use of primary data to compliment the available secondary data. As a result, interview guide and participant observation were used in the study. The interview guide designed for this study was developed by the researcher based on the objectives of the study. The interview guide was administered on sample drawn among Bodija market beans and onion traders between 12 and 16 March, 2014. The interview guide sought to build a narrative about the respective issue in question. The respondents were allowed freedom to express themselves on issues of livelihood that are culturally considered private. Due to limited resources at our disposal and ease of analysis 30 copies of interview guide containing 10 questions were administered. Also, interview guide was also translated into Yoruba for better understanding. Direct observation was also employed by the researcher to assess, among other things, the physical condition of the market, the condition of the commodities under study. Data analysis was based on the objectives of the study to examine the impact of insurgency on food security in Ibadan and how insurgency affects food supply chain with an attempt to examine the coping strategies in food shortages. Transcription was used for analyzing data generated from the interview guide. Comments were made according to the perception of the researcher based on observation.

\section{Conceptual Clarifications}

\subsection{Food Security}

Food security is a broad term, which is defined in different ways by a number of organizations and researchers around the world. Simply put, food security refers to the ability of all people to obtain sufficient nutritious food on a dayto-day basis. In essence food security is the ability of people to secure adequate food. More especially it has been defined variously by researchers but the rallying point is the access by all people at all times to enough food for an active healthy life. Food security in its most basic form is defined as the access to all people to the food needed for a healthy life at all times (see Eide, 1999:3).

In the 1996 Rome declaration on world food security, food security is defined as: 'Food that is available at all times, to which all persons have means of access that is nutritionally adequate in terms of quantity, quality and variety, and is acceptable within the given culture' (cited in Clover, 2003:7). In a simple language, a country is food-secure when majority of its population have access to food of adequate quantity and quality consistent with decent existence at all times (Idachaba, 2004:2). Odey cited in Jerome (2012) articulates food security system definition as the availability and accessibility of food stuff in desired quality to all consumers throughout the year. (Gokum 2007) defines food security as the availability at all times of adequate world food supplies of basic food stuff to sustain a steady expansion of food consumption and to offset fluctuation in production and prices. Food security is the condition in which all have access to sufficient food to live healthy and productive lives (World Bank, 1986). United States Agency for International Development (USAID) Bureau for Africa, cited in Adeboye (2015) defined food security as a situation 'When all people at all times have physical, social and economic access to sufficient food to meet their dietary needs for a productive and healthy life'.

What is implied in these definitions is that food must be available to the people to an extent that will meet some acceptable level of nutritional standards in terms of a calorie, protein and minerals which the body needs; the possession of the means by the people to acquire (i.e. access) and reasonable continuity and consistency in its supply (Davies, 2009:4). In other words, food security can be taken to mean access by all people at all times to sufficient food for an active, health life. Its central elements are: (a) the availability of food and (b) the possession of the ability for its acquisition (Adeoti, 
1989:117). Food security is multi-dimensional. There are about four Dimensions of Food Security. These include: Physical availability of food, Economic and physical access to food, Food utilization - with sufficient energy and nutrients and, Stability of the other three dimensions over time (FA0, 2002). Food availability addresses the'supply side'of food security and is determined by the level of food production, stock levels and net trade. Food utilization is commonly understood as the way the body makes the most of various nutrients in the food. The ability to access food rests on two pillars: economic and physical access. Economic access is determined by disposable income, food prices and the provision of and access to social support. Physical access is determined by the availability and quality of infrastructure, including ports, roads, railways, communication and food storage facilities and other installations that facilitate the functioning of markets. Incomes earned in agriculture, forests, fisheries and aquaculture play a primary role in determining food security outcomesStability: Even if your food intake is adequate today, you are still considered to be food insecure if you have inadequate access to food on a periodic basis, risking a deterioration of your nutritional status. (Adeoti, 1989:117; Davies,2009; and FAO cited in Adebayo (2015:25)

\subsection{Insurgency}

Insurgency can be defined as a legitimacy crisis, where by one or several aspects of a state are challenged, ranging from legitimacy of a state itself,to the legitimacy of its political and social order, a particular government or its certain policies (O’Neill, 2005). The British Army counter-insurgency manual, Army Field Manual (AFM) cited in Adeboye (2015:29) defined insurgency as: "The actions of a minority group within a state, who are intent on forcing political change by a means of a mixture of subversion, propaganda and military pressure, aiming to persuade or intimidate the broad mass of the people to accept such a change. It is an organized, armed political struggle, the goals of which might be diverse.'Metz and Millen explained that: 'Insurgency is a strategy adopted by groups which cannot attain their political objectives through conventional means or by a quick seizure of power. It is used by those too weak to do otherwise. Insurgency is characterized by protracted, asymmetric violence, ambiguity, the use of complex terrain (jungles, mountains, and urban areas), psychological warfare, and political mobilization all designed to protect the insurgents and eventually alter the balance of power in their favour'. (Metz and Millen, 2004).According to Kilcullen, 'Insurgency is a struggle to control a contested political space, between a state (and a group of states or occupying powers), and one or more popularly based, non-state challengers' (Kilcullen 2006: 112). Kilcullen also try to draw a line between classical and contemporary insurgencies thus: while the latter seek to replace the existing order, the former sometimes strive for the expulsion of foreign invaders from their territory or seek to fill an existing power vacuum (Kilcullen 2006: 112). Basically, insurgents often pursue some common objectives targeted at undermining the legitimacy of the government while increasing their own ties with the population. According to the 2012 'Guide to the Analysis of Insurgency' published by the US Government, cited by Adeboye, (2015:31) insurgencies seek to accomplish the followings:

...Undercut the ability of the government to provide the population security and public services, including utilities, education, and justice. An insurgent group may attempt to supplant the government by providing alternative services to the people, or it may be content to portray the government as impotent... Obtain the active or passive support of the population. Not all support has to be or is likely to be gained from true sympathizers; fear and intimidation can gain the acquiescence of many people. Provoke the government into committing abuses that drive neutral civilians toward the insurgents and solidify the loyalty of insurgent supporters...Undermine international support for the government and, if possible, gain international recognition or assistance for the insurgency

In all, insurgencies connote an internal uprising often outside the confines of state's laws and it is often characterized by social-economic and political goals as well as military or guerrilla tactics. Put differently, it is a protracted struggle carefully and methodically carried out to achieve certain goals with an eventual aim of replacing the existing power structure. To launch their anger on the state, insurgents often target civilians and infrastructures. Its strategic objective is to shape the public's perception of the legitimacy aspect which comes under challenge. Violence is employed as a means of persuasion which helps to discredit the state, political order, government or its policy, attract and mobilizing supporters, intimidate opponents of insurgency and isolate them from the government. Metz and Millen call this 'armed propaganda' which also assists political mobilization (Metz and Millen, 2004). In any case, insurgency and counter insurgency usually is a long war, lasting for years and even decades, where both sides are simply seeking to outlast each other. For this reason, Mao calls his model of insurgency 'a protracted people's war'.

\section{Background to Boko Haram Insurgency in Nigeria}

The history of Boko Haram shows that the sect grew out of a group of radical Islamist youth who worshipped at the Al- Haji Muhammadu Ndimi Mosque in Maiduguri, capital of Borno state, in the 1990s (Walker, 2012) and was led by Yusuf until he was killed by Nigerian security forces following sectarian violence that broke out in July 2009 during which over 700 people were also killed. At the time of his death, Yusuf was the commander-in-chief (Amir ul-Aam) of Boko Haram (BBC News August 26, 2011). Mohammed Yusuf began as a preacher and leader operating under a prayer group which he called 'Jama'atul Alhul Sunnah Lidda'wati wal Jihad' loosely translated in Arabic as 'people committed to the propagation of the Prophet's teachings and jihad. His literal interpretation of the Quran led him to advocate that aspects of Western education he considered in contradiction to the holy book, such as evolution, the big bang theory of the universe's development and elements of chemistry and geography, should be forbidden. 'Boko Haram' (NIPSS, 2012). Boko Haram's principal goal is to create a strict Islamic state in the north that it believes would address the ills of society, including corruption and bad governance. The sect's core beliefs are strict adherence to the Quran and the Hadith (sayings of the Prophet Muhammed), and their interpretation as sanctioned by Ibn Taymiyyah (the preferred scholar of Mohammed 
Yusuf, the sect's leader). Yusuf was always political, wanting an Islamic government, but not violent. That changed over time as more radical lieutenants pushed the movement in more confrontational directions. State harassment and perceptions that agreements had gone unfulfilled escalated into vicious conflict. The death Mohammed Yusuf\&\#39; , the leader of sect and his deputy-Alhaji Buji Foi marked a turning point in the activities of the group. The killing of the duo was initially celebrated by the government and security agents as a major breakthrough in curbing the bloody violence from the Boko Haram group but later turned out to be a sour grape. The reason for this is as soon as the news broke that the arrested sect leaders of the notorious Islamic sect were killed, human rights activists and amnesty group went to town, condemning the killing of Yusuf and Foi by the police, describing it as another of the numerous cases of extra-judicial killings by the police. With the summary execution of the sect leaders, whatever information that could have been extracted from the sect leaders through interrogation and investigation has now been lost. According to Toni Johnson of the Council on Foreign Relations, Yusuf originally intended his Salafst prayer and self-isolation movement to promote the religion of Islam and encourage the enforcement of Sharia law in the country's Northern states (Johnson, 2011). He attracted mostly disaffected young people and unemployed university students and graduates, many of them animated by deep-seated socioeconomic and political grievances like poor governance and corruption. In essence, Boko Haram as the group came to be called by locals, press and eventually by the government, because of its anti-Western focus sought to create a 'better' Nigeria through strict adherence to Islam. Over time, the group's members saw themselves increasingly at odds with the secular authorities, whom they came to view as representatives of a corrupt, illegitimate, Christiandominated federal government, (Leadership 24 July 2011). Their disappointment in local government leaders was worsened in the summer of 2009, when authorities in Bauchi refused to allow them to preach and recruit publicly. This brief period marked another turning point for Boko Haram. Imam Shekau the new leaders were considered to be extremely more radical than Yusuf was. (This Day September 20, 2010). For many members of the sect, the unjust circumstances surrounding the death of Yusuf served to amplify pre-existing animosities toward the government. The Boko Haram's main affiliation is the Jama'tIzalat al Bida'aWaIqamat as Sunna (Society of Removal of Innovation and Reestablishment of the Sunna). This movement is a Wahhabi, anti-Sufi movement established in 1978 in Jos by Sheikh Ismaila Idris (1937-2000). It was one of the fast-growing Islamic reform movements in Nigeria, shaped by the teachings of Sheikh Abubakar Gumi (Michael, 2012). Boko Haram's modus operandi has involved the use of gunmen on motorbikes, assassinating policemen, politicians, or anyone critical of the group, including Muslim clerics who disclose information regarding their whereabouts to state security services (HRW, 2012). Increasingly, suicide bombing has become a major strategy for Boko Haram. For many members, the extrajudicial killing of their founder served to foment pre-existing animosities toward the Nigerian government and its security forces. In the group's bid to avenge the death of its founder, almost every individual and group outside Boko Haram's network was impacted, particularly the Nigerian police and army. Boko Haram's most frequent targets have been police stations, patrols, and individual policemen at home or in public including those who were off- duty or retired (Agbiboa, 2013). They have used petrol bombs, improvised explosive devices, and armed assaults in these violent attacks (Forest 2012; HRW, 2012). However, Boko Haram became a fullfledged insurgency following confrontations between the group and Bauchi State's security agency, charged with enforcing a newly introduced law that required motorcyclists in the entire country to wear crash-helmets (Uzodike, 2012). Members of Boko Haram refused to obey this law. This led to a violent clash between the state's enforcement agency and the group which left 17 Boko Haram members dead. The group's hideout in Bauchi State was also ransacked and materials for making explosives were confiscated. Following this crackdown, the group mobilized its members for reprisal attacks which led to the deaths of several policemen and civilians (Abgiboa, 2013). The riot was temporarily quelled after Nigerian forces captured and killed the Boko Haram leader, Yusuf. Following the death of Yusuf, and the arrest of several of Boko Haram members, the group retreated for a while, but only to recuperate. The killing of their founder pushed the movement to transform itself into a network of underground cells with a hidden leadership - a situation that today makes any military solution illusory' (Agbiboa, 2013). The extent of relative poverty and inequality in the north has led several analysts and organizations to argue that socio-economic deprivation is the main factor behind Boko Haram's campaign of violence in Northern Nigeria (Agbiboa, 2013; Mustapha, 2012; Kukah, 2012). They argue that Boko Haram communities are wrecked by 'poverty, deteriorating social services and infrastructure, educational backwardness, rising numbers of unemployed graduates, massive numbers of unemployed youths, dwindling fortunes in agriculture...and the weak and dwindling productive base of the Northern economy'. According to International Crisis Group, bad governance, sustained economic hardship, rising inequality and social frustration are fostering the growth of radical extremist groups in Nigeria (ICG; 2014:1). It has become a major challenge for the region and the whole country. Kwaja toes a similar line in arguing that 'religious dimensions of the conflict have been misconstrued as the primary driver of violence when, in fact, disenfranchisement and inequality are the root causes' (Kwaja, 2011). Also, Kukah argues that religion is used to mobilize against modernity, which is seen as the root cause of social anomalies. In his words, 'The evil effects of bad governance, corruption, total lack of security and welfare have all become part of our daily lives. Clearly, in the eyes of the sect members, the persistence of corruption, collapse of public morality, injustice and so on could only be attributed to those who govern. In their reasoning, those who govern us do so because they have acquired their tools by gaining Western education.' Evans posits that 'a downward spiral of economic decline, often exacerbated by official corruption and mismanagement, has created governments that are at or near the point of collapse and that are being challenged, often violently, by their own citizens' (Evans, 1994).

\section{Data Presentation and Analysis on Impact of Insurgency on food Security in Ibadan}

The researcher discovered that as it is always the case in conflict situations, this food producing region has experienced destruction of food stocks, livestock and other assets, interruption of market supplies of food not only in the 
region but also in neighboring regions. The predatory activities have diminished food availability and food access directly, because both insurgents and other unidentified elements in the field tend to subsist by extorting the unarmed populations for food and any other productive resources. Bearing these risks in mind, the farming populations tend to flee, decline or stop farming.

According to Lasisi a 46 years old trader stated during the field visits that:

The insurgency has changed the face of faming in the North-East that was renowned for cereal farming of large scale. Agriculture in the affected area has reduced to subsistence and survival production by few farmers who manage to stay, because there is no incentive to invest deeply in production.

From the above view expressed by Lasisi insurgency tends to cause food insecurity by creating food shortages. Many able farmers would have died or displaced from their farms to a safe haven by the insurgency. In the process some crops might waste away or be destroyed. As it is always the case in any crisis situation farming populations would prefer to flee until normalcy returns. This is in line with FAO 2002b report that civil strife affects food security in developing countries due to its detrimental effects on the agricultural sector and on the economy as a whole.

In the words of Amope, 37; trader, commented on the scarcity being experienced at Bodija market as follows:

How I wish our customers would understand that we are not responsible for the current scarcity of food. We can only pray and appeal to the government to put an end to insurgency. Otherwise the situation would persist until there is a solution.

In the same vein, Olajire, 45 , a beans seller attributed the drastic reduction in food availability at Bodija market to reduction in the number of traders since the insurgency began. According to him:

Shortly after the 2013 saga when we lost some of our members and millions of Naira to the insurgency fear gripped most of the traders. Some began to change their businesses some even left the market to become commercial motorbike riders when they could no longer cope with the new reality

The reduction in the food available and sales at Bodija market was captured clearly by Idris 32; trader, during the interview when he, said:

Bodija market used to be a busy market, everything has changed. Most beans shops used to be stocked to capacity before the insurgency and customers use to take turn to buy goods. Now it is a thing of the past as occasioned by the insurgency. Perhaps those who are benefitting are the middlemen but definitely not we the sellers or the customers who daily complain of the scarcity whenever they come around.

The reduction in food availability at the market was observed by the researcher. As at the time of the field work no single shop was dedicated to the sales of onion. One could count on the finger tips the numbers of people selling onion.

Majority of those selling onions were Hausa traders while others were from other ethnic groups, mostly Yoruba. All of them displayed their wares along the market road network; an indication that no serious onions- business is going on at a time when onions supposed to flood the market. The shortages were blamed on the spate of insurgency in the North-East by the traders.

The result from the interview gives detail explanations for the food shortage. The supply of food to Ibadan from the North-East was affected by low agricultural production caused by disruption of farming activities and the displacement of farmers. Of the two food items under study onion was more affected than the honey beans. The cost of supplying onions to Ibadan has changed astronomically. Most traders from other ethnic groups have left onion business to the few Hausa who literally displayed their wares in open spaces along the market road network.

A 68-year-old onion seller fondly called mama Limota has this to say:

The activities of the insurgents are creating a lot of discomfort to us we can no longer go to

the North or send somebody to buy onions for us. Majority of my colleagues have left the

business due to high cost of supply. 'A basket consisting of 40 big size bulbs of onions used

to go for N800 before the insurgency. The story has changed; we now buy it for N1800.

Even though, we are in the season of onions yet the price is high, you can imagine how much onions will cost during the off season.

As a result of the scarcity of the produce especially onions majority of the traders have changed to other businesses or perhaps left the market entirely, as the case may be. Tawa 37; onions seller said categorically:

Despite what we are going through I continue in this business so as not to be idle. As soon as I can raise enough capital to venture into another business, I will quit. Market is dull due to scarcity of onions from the North-East. The insurgency has displaced the produce farmers. Imagine, December to March supposes to be the season for onions yet it is very scarce now.

Similarly, from the field work it was gathered that; insurgency has created fear of insecurity in the mind of traders under study. This cannot be dissociated from the loss of some of traders to insurgency in 2013. As stated early in the study 24 traders were allegedly killed by suspected members of Boko Haram sect on their way to Borno State ostensibly to buy food stuff. Some traders at Bodija market are still counting their losses while all of them share the view that nothing can make them fall prey again to the insurgency. Abdul Adeogun 35; a trader who lost two of his relations to the insurgency has this to say:

Hmn talking about the insurgency is like opening an incurable sore. I lost two of my relations to the insurgency in 2013 in addition to huge amount of money I sent through the victims. If 
not for my friends that offered me credit facilities I would have been ruined. Look at the market we were more than this before the insurgency. Some had left for other businesses because things are tougher now, as you can see traders are few and food items are scarce too.

The insurgency has created fear in the traders especially having lost some of their colleagues in 2013 on their way to Borno State. The trade routes in the North-East are no longer safe for business activities.

\section{Potential Effects of Insurgency on Food Supply Chain}

The insurgency has altered the trade pattern. Forces of insurgency instead of forces of demand and supply now control the market situation. The seasonal changes that each crop is known for, has also been altered.

The reduction in sales at Bodija market was captured clearly by Dauda 41; trader when he said during the field visits that: Most of our regular customers are no longer regular at the market. Even when they visit the market they do not purchase as they used to do. The effect of scarcity is affecting all of us. Most times our customers complain of lack of money to buy food stuff in bulk.

The effect of food shortages being witnessed in Ibadan is compounded by the economic hardship in the country, most time the available money is inadequate to satisfy numerous needs. As such times most people skip some meals so as to attend to other potent needs.

Insurgency like any other violent conflict disturbs farming activities since insurgency always disrupts production and distribution networks. The low agricultural productivity caused by insurgency, creates scarcity of commodities under study. Insurgency is indeed a major driver of food insecurity. In the North East insurgency has disrupted market access, causing cereal prices increase sharply by 80-100 percent above the average from late 2010 . The study reveals that in 2010 a 'Mudu' (unit of measurement) of beans was sold for N200. The same measurement goes for between N350 and N400 in 2015.

Oluwole Adebayo 26, a 200-level undergraduate, department of Agriculture, University of Ibadan, who came to the shop to see his mother volunteered to be interviewed and commented on the agricultural activities in the North-East:

My interactions with the middlemen show that farming activities have been disrupted in the North-

East by the insurgency and the militaristic counterinsurgency efforts. Skeletal farming activities now go on. The middlemen virtually scout for commodities at some remote farms. Most farmers have been killed or displaced from the region. Bearing these risks in mind, the farming populations tend to flee, decline or stop farming. Agriculture may be reduced to subsistence and survival production by farmers who manage to stay, because there is no incentive to invest deeply in production. Recruitment of young male men into militias and thousands of battle-related deaths not only will reduce family income but also take away labour from agriculture.

This is in line withPierre Wilner Jeanty and Fred Hitzhusen (2006) Conflicts tend to affect food security by creating food shortages. Civil strife affects food security in developing countries due to its detrimental effects on the agricultural sector and on the economy as a whole.

Insurgency with its attendant food shortages have brought about scarcity of commodities. Traders as well as consumers are both affected. All the respondents complained about fall in demand of commodities as occasioned by the insurgency. Low business activities characterized the market as observed during the field work. If a fall in demand of a commodity implies a change in the consumption pattern of the consumer then this comment from Adegbola, 33; trader at Bodija market would be of essence:

Sales of beans have reduced drastically. You may be surprised that it takes me at times two weeks to sell a bag of beans nowadays unlike in the past when beans business was booming. Before the insurgency I sold on the average one bag of beans in two days.

\section{The Coping Strategies in Food Shortages}

In order to live through difficult time straders have resorted to coping strategies involving the use of indigenous Northerners as food suppliers or middlemen, reduction in supply due to insufficient capital. In the words of Nafisat, 22, a 100-level undergraduate, department of Economics, University of Ibadan commented on food shortages at Bodija market as follows:

Aside from the fact that no serious farming activities is going on in most places in the NorthEast the activities of the middlemen contribute to scarcity we are now experiencing. The cost price is high so also will be the selling price. People are no longer patronizing us as before. Since we deal in perishable items, we have to buy the much we can handle.

In a bid to find a way out of fear of insecurity, supply of food to Ibadan is now conducted through the use of middle men. As relieving as this development appears it is not without side effects. The Hausa traders who understand the business routes and terrain well now scout for food items from local farmers and supply them to traders in Ibadan. The procedure is that traders pay a-head and goods are sent as soon as they are available. The danger in the arrangement according to some respondents is that the arrangement suffered abuse initially; some traders fell into wrong elements who paraded themselves as businessmen. However, the recurring challenges being faced with the use of middlemen is arbitrary packaging of beans. About this coping strategy Fausat, 48; trader has this to say:

We are just working for the Hausa middlemen. Apart from the fact that most time they bring to us produce that ordinarily we would consider unfit, $20 \%$ of beans would be tares, we are paying more than before; the worst is that the business has become unpredictable. We cannot 
differentiate between season and off season. It is difficult to predict price anymore. Whenever insurgents strike the cost of supply will increase, the business is just volatile.

Oluwole Adebayo 26, a 200-level undergraduate, department of Agriculture, University of Ibadan, who came to the shop to see his mother volunteered to be interviewed. In his words:

Precarious as the activities of the middlemen might seem we must commend them for their bravery. They are risking their lives to bring us food. We are actually living on their bravery. They are equally as vulnerable as the traders here; the only difference is that they understand the terrain more than strangers.

According to Oluwole Adebayo he had personally interacted with some of middlemen and their experience in the face of the insurgency is horrible. As far as the period of the insurgency is concerned the services of the middlemen will be needed, otherwise the region may be cut off completely from southerners who are scared by the insurgency.

On the loss of some of their colleagues to the insurgency in 2013 and the menaces of the middlemen, the traders want more than sympathy from the government. It was gathered from the field that more should be done by the state government to ensure food availability in the prevailing insurgency. Alhaji Agba 52, trader has this to say:

We are trying our best to continue to ensure food availability in Ibadan. However, there is a limit to what we could achieve alone. We want the state government to intervene in the activities of the middlemen by creating a quality control post in the market. This would introduce sanity into the food supply chain since we can no longer embark on any business trip to the North-East again

Similarly, on behalf of Bodija market traders Mustapha 45, as implored that:

How we desire to get more than the sympathy given to us when we lost some of our co-traders and hard-earned capital to the insurgency in 2013. Frankly speaking, some of us that lost money to the incidence and are still in business are shadows of our past. It is not too late for the government to help us. We thank the State government for the compensation given for the traders that were killed by the insurgents. But we need financial support from the government to revive our business. By so doing most of our colleagues that left the market can return to beef up the manpower needed for more food availability in Ibadan.

Empowering people in the agriculture value chain, if properly managed, would address the empowerment need of traders that are personate but lack financial resources, in ensuring food security in the face of prevailing insurgency.

Similar reactions are noticed in the interview Adedigba, 43 charged Oyo state government on food availability in Ibadan as he expressed concern about perceived indifference of the state government to the current food situation in the state, thus:

Ibadan is the biggest city in West Africa it thus implies that the State government should go extra mile to make food available at all times. Though the government is trying in her various agricultural projects all over the state but one should ask: what is the government doing on crops that are not produced in the state? There should be food reserves where those essential rare food items could be purchased and stored during the harvest time when they are cheaper.

As brilliant as Adedigba's idea was recent emphasis on privatization policy suggests that government is not interested in doing business. The truth is that serious issues as food security should be addressed specially. The food availability successes so far recorded in USA even in Southern Africa were as a result of the windows of opportunity created by the respective government to boost agricultural productivity.

Fausat 33, has an alternative view to the one shared by the like of Adedigba:

As a matter of facts most of these new crops could be cultivated here in Oyo State if the government is

personate about it. They can start with onions which I know can grow in swampy areas just like rice.

In this era of great possibilities new crops can be introduced to boost food availability in places where they dearly needed it. Oyo state ministry of Agriculture and relevant institutions should contribute to growing new essential crops for the benefit of the teaming populations in Ibadan.

In order to live through difficulttimestraders have resorted to coping strategies involving cutting down the quantity of supply ordered due to insufficient capital, In the words of Nafisat, 22, a 100 level undergraduate, department of Economics, University of Ibadan, who was at the market to assist her sick mother, commented on food shortages at Bodija market as follows:

Aside from the fact that no serious farming activities is going on in most places in the North-

East the activities of the middlemen contribute to scarcity we are now experiencing. The cost

price is high so also will be the selling price. People are no longer patronizing us as before.

Since we deal in perishable items, we have to buy the much we can handle.

This coping strategy was rampant among most of the respondents who have insufficient capital base. This explains the reasons why most of the shops observed during the field work were not well stocked. The implication of this coping strategy is that food shortages would persist.

Some of the traders in a bid to cope with situations created by the insurgency are pooling resources together to facilitate bulk purchase of commodities. This arrangement allows the cooperating traders to be in business. This is a welcome idea with prospect of ameliorating the financial challenges of the traders concerned. The benefit of the coping strategy was succinctly expressed by Anike 27, beans trader:

I never knew I would survive the loss of capital I incurred in 2013 when the insurgents killed my

business partner on her way to Borno state. Most of us that suffered the same fate have to team up before we could buy reasonable commodities since then. 
Those traders that are not in alliance with others have to embark on self-help to cope with the challenges created by insurgency. This they did by selling off non-essential assets to boost their capital. This is a usual practice among the indigents to keep their heads above the water:

Ajeigbe narrated how he sold some assets to boost his onion business:

I am one of the lucky people that escaped from Yobe before insurgency escalated in 2012. I managed

to pack some of my belongings which I later sold to start my business at Ibadan. I know quite a

number of us that were displaced by the insurgency that did likewise and life goes on.

Most traders that were displaced from the North-East are adopting this coping strategy. In spite of the sacrifice they made to boost their capital they are still operating at a low capacity. This on its own contributes to low food availability in Bodija market.

The scarcity of commodities has led to fall in demand. This does not augur well with those selling perishable commodities as onion. Thus, some traders prefer to concentrate on commodities with minimum handling risk while others abandoned food stuff business completely.

Johnson, 38, onions traders confessed that:

As a result of scarcity of onion demand for onion is falling. Most time some of the commodities become

bad because demand is poor. My plan is to change over to other commodities with lesser handling risks

instead of abandoning business as some have done.

The risk of running into shortages of perishable commodities is higher as a result of the insurgency. The ultimate goal of a business man is to make profit. It may be expedient for traders in perishable commodities that are scarce to quit the commodities. The more traders quit the commodities the more food shortages would deepen.

\section{Conclusion}

The study reveals effects of insurgency on food security in Ibadan. Insurgency tends to affect food security by creating food shortages, which disrupt both, upstream input markets and downstream output markets, thus deterring food production, commercialization and stock management. In the North-East where the insurgency is mostly located, crops cannot be planted, weeded or harvested as before. This has dramatically changed the levels of agricultural production of the region that was known to have comparative advantage in the production of appreciable numbers of food crops for the nation. The researcher discovered that as it is always the case in conflict situations, this food producing region has experienced seizing or destroying of food stocks, livestock and other assets, interruption of market supplies of food not only in the region but also in neighboring regions. These predatory activities diminish food availability and food access directly, because both insurgents and other unidentified elements in the field would tend to subsist by extorting the unarmed populations for food and any other productive resources. Bearing these risks in mind, the farming populations would tend to flee, decline or stop farming. The hostile environment created by insurgency hinders agricultural activities; food production, commercialization and stock management in the North-East. Consequently, regions that depend on food supply from the North-East are facing the effect of food shortages. The effects of insurgency on food availability in Ibadan are best appreciated by comparing the situation before the insurgency with the current food availability situation caused by the insurgency. The assessment compares the normal food availability situation and the current situation. Comparisons between the two allow us to decide how and why the situation has deteriorated. This is a step towards understanding the needs that arise due to a hazard or chronic crisis as the current insurgency and determining the best response.

\section{Recommendations}

- Make agriculture the central part of the government policy: Food security exists when all people, at all times, have physical and economic access to sufficient safe and nutritious food that meets their dietary needs and food preferences for an active and healthy life. Andagriculture plays a major role in attaining food security. Therefore, making agriculture work must be central component of government policy approaches to food insecurity reduction and increasing economic growth. Providing adequate security and improving investment in agriculture will help redress the current downturn of faming activities in the North-East.

- 2.Confidence building through empathy and advocacy: The federal government should demonstrate commitment in addressing the security challenges created by the insurgency without compromising the safety and livelihood of the people in the North-East. Farm settlements can be set up in places not directly at the risk of the insurgency and manned with dedicated military presence. Farm land should be duly provided by the government to avoid new conflict over land.

- Improved government presence in the region: One of the reasons that brought about the insurgency was the prevalence of poverty in the North-East. In order to erode support for the course of the insurgency government should embark on a massive reconstruction of the region.

- Empowerment: Government should take the census of farmers that lost farm produce and live stocks to the insurgency for the purpose of compensation. However, to avoid diversion of fund, the compensation should take the form of micro credit facilities, input supplies and agric extension services.

- Intensification of agricultural projects in the south west: The various state governments in the south west should collectively intensify agricultural project in the region to ensure food security. Effort should be made to effectively maximize the ample arable of the south west to provide food for the citizenry. The region was formerly known for food security hence, effort should be made to mobilize resources towards replacing subsistence farming with mechanized farming in the region. 
- Local production of new crops: Oyo state government should take advantage of the ample arable land in the state by venturing into cultivation of new crops such as beans and onions for the food security need of the state. This could be done in conjunction with International Institute of Tropical agriculture (IITA) and other colleges and research institutions for the production of essential crops that are presently not cultivated in Oyo State. The scheme could be direct involvement of Oyo State Ministry of agriculture and Water Resources appropriate ministry or by encouraging private participation or the fusion of the two.

- Revitalization of the state grain reserve: Oyo state government should revive the state grain reserve by storing grains which are usually cheap during the harvest period. This would alleviate food shortage during the off season or any emergencies

- Commodity importation: Food availability can be achieved through improved agricultural activities, aid or importation of food stuffs. Should the insurgency persist government intervention may be temporarily necessary, through importation of food stuffs.

- Effective national food policy: The effect of insurgency on food security situation of the country has brought about new reality. There is a high degree of interconnection between the Southern and the Northern Nigeria. As discussed earlier about $50 \%$ of the food needs of the South come from the North. Protracted insurgency activities would impose serious food insecurity on the nation. Hence government should come up with viable national food security program that would address national food security. Centers should be located within each of the 6 geo political zones of Nigeria for effectiveness.

- Suitable intervention programme: There is the need for concern individuals, NGO, national and international organizations to embark on intervention programmes that would alleviate food shortages currently being witnessed in the face of the prevailing insurgency such as: food security advocacy, food aid, free food for the vulnerable groups and the like.

\section{References}

i. Adeboye, F. I. (2015).'Impact Assessment of Insurgency on Food Security in Ibadan'. Unpublished Masters Dissertation in Peace and Conflict Studies, Institute of African Studies, University of Ibadan, Ibadan, Nigeria.

ii. Ademola, F. S. (2012). Theories of Social Conflict, UPEACE Africa Programme, Spectrum Books Limited, Ibadan.

iii. Adeoti, J. A. (1989).'Economic Crisis in Developing Countries: The Food Dimension', Ilorin Journal of Business and Social Sciences, Vol.1.

iv. Agbiboa, D. E. (2013). No Retreat, no Surrender: Understanding the Religious Terrorism of Boko Haram. African Study Monographs, 34 (2), pp. 65-84.

v. BBC News (2013b). 'Nigerian Army Destroys Boko Haram Camps in Northeast'. 24 May.

vi. Clover, J. (2003). Food Security in Sub-Saharan Africa, African Security Review, Vol. 12, No.1.

vii. Davies, A. E. (2009).'Food Security Initiatives in Nigeria: Prospects and Challenges', Monograph, Department of Political Science, University of Ilorin, Nigeria.

viii. Eide, A. (1999).'Globalization, Universalization and the Human Right to Adequate Food', in Ogunrinade A, Oniango, R. and May, J. (Eds), Not by Bread Alone', Food Security and Governance in Africa. South Africa: Institute for Global Peace and Policy Research.

ix. Evans, G. (1994). 'Cooperative Security and Intrastate Conflict'. Foreign Policy 96:3

x. FAO (2002). The State at Food Insecurity in the World 2002' Food and Agriculture Organisation.

xi. Forest, J. J. F. (2012) Confronting the Terrorism of Boko Haram in Nigeria. Florida: The JSOU Press.

xii. Gokum, G. G. (2007),'Agricultural Development Programs and Food Security in Nigerian (1970-2004)'in Ogiji P. (ed). The Nigerian Economy: Challenges \& Directions for Growth in the Next 25 Years

xiii. Human Rights Watch (2012), 'Nigeria: Massive Destruction, Deaths from Military Raid,' Baga Town, Borno State, 1 May 2013; Amnesty International, Nigeria: Trapped in a Cycle of Violence, November.

xiv. Idachaba, F. (2004).'Food Security in N i g e r i a Challenges under Democratic Dispensation', paper presented at ARMTI, Ilorin, Kwara State(March 24).

xv. International Crisis Group (2014). Curbing violence in Nigeria (11): The Boko Haram Insurgency. Africa Report, No 216, pp. 1-54.

xvi. Jeanty, P. W. and Hitzhusen, F. (2006). Analyzing the Effects of Conflicts on Food Security in Developing Countries: An Instrumental Variable Panel Data Approach, Selected Paper prepared for presentation at the American Agricultural Economics Association, Annual Meeting, Long Beach, California, July 23-26.

xvii. Jerome, A. (2012).'Nigeria's Food Security Programs: Implications for MDG's Goal of Extreme Hunger Eradication'. International Journal of Business and Social Science Vol. 3 No. 9; May 2012243

xviii. Kilcullen,D. J. (2004), 'Countering Global Insurgency' in Small War Journals.

xix. Kukah, M. H. (2012). 'Nigeria: Country as an Emerging Democracy: The Dilemma and the Promise'. Daily Trust (Abuja).

xx. Kwaja, C. (2011). Nigeria's Pernicious Drivers of Ethno-Religious Conflicts. African Press pp 25-30.

xxi. Marchal, R. (2012). Boko Haram and the Resilience of Military Islam in Northern Nigeria'. Report, Norwegian Peace building Resource centre.

http://www.peacebuilding.no/var/ezflow_site/storage/original/application/dc58a110fb3624701333

xxii. Maslow, A. (1943). 'A Theory of Human Motivation'. In Psychological Review50 (4):370-396. 
xxiii. Metz S., Millen R. (2004).Insurgency and Counter insurgency in the $21^{\text {st Century: Reconceptualizing Threat }}$ and Response, Carlyle: US Army War College Strategic Studies Institute, p. 2.

xxiv. Mustapha, A. R. (2012). 'Boko Haram: Killing in God's Name'. Mail and Guardian,

xxv. NIPSS (2012).'Insurgency in Nigeria: Islamism and Militancy in Northern Nigeria', Discussion Paper Presented at the National Institute of Policy and Strategic Studies (NIPSS), Kuru, Plateaustate, 10July.

xxvi. O'Neill, B. (2005).Insurgency and Terrorism: From Revolution to Apocalypse, Washington: Potomac Books, p.15.

xxvii. Rosati, J. A., Carroll, D. J. and Roger, A. C. (1990).'A Critical Assessment of the Power of Human Needs in World Society' In: Burton, J and Dukes, F (eds.) Conflict: Readings in Management and Resolution. Basingstoke: B Press, pp. 156159.

xxviii. Uzodike, O. and Maiangwa, B. (2012). 'Boko Haram in Nigeria: causal Factors and Central Problematic.' African Renaissance: Terrorism in Africa 9(1):91-118

xxix. Walker, A. (2012).'What is Boko Haram?'U.S. Institute ofPeace (USIP), June 2012, p. 3.

xxx. World Bank (1986). Poverty and Hanger: Issues and Options in Developing Countries, A World Bank Policy Study, Washington, D.C: World Bankwww.iss.co.za/pubs/books/unesco/naidoo.html

xxxi. News Papers

xxxii. Daily Trust, (8 August 2013)

xxxiii. Leadership (24 July 2011).

xxxiv. Tell Magazine, (May 5, 2008)

xxxv. The Sun; (3 Feb., 2014).

xxxvi. This Day (September 20, 2010) 